\title{
Immune gene expression in the spleen of chickens experimentally infected with Ascaridia galli
}

Dalgaard, Tina S.; Skovgaard, Kerstin; Norup, Liselotte R.; Pleidrup, Janne; Permin, Anders; Schou, Torben W.; Vadekær, Dorte Fink; Jungersen, Gregers; Juul-Madsen, Helle R.

Published in:

Veterinary Immunology and Immunopathology

Link to article, DOI:

10.1016/j.vetimm.2015.01.003

Publication date:

2015

Document Version

Peer reviewed version

Link back to DTU Orbit

Citation (APA):

Dalgaard, T. S., Skovgaard, K., Norup, L. R., Pleidrup, J., Permin, A., Schou, T. W., Vadekær, D. F., Jungersen, G., \& Juul-Madsen, H. R. (2015). Immune gene expression in the spleen of chickens experimentally infected with Ascaridia galli. Veterinary Immunology and Immunopathology, 164(1-2), 79-86.

https://doi.org/10.1016/j.vetimm.2015.01.003

\section{General rights}

Copyright and moral rights for the publications made accessible in the public portal are retained by the authors and/or other copyright owners and it is a condition of accessing publications that users recognise and abide by the legal requirements associated with these rights.

- Users may download and print one copy of any publication from the public portal for the purpose of private study or research.

- You may not further distribute the material or use it for any profit-making activity or commercial gain

- You may freely distribute the URL identifying the publication in the public portal 
1 Immune gene expression in the spleen of chickens experimentally infected with 2 Ascaridia galli

3

4

5 Tina S. Dalgaard* ${ }^{1}$, Kerstin Skovgaard ${ }^{2}$, Liselotte R. Norup ${ }^{1}$, Janne Pleidrup ${ }^{1}$, Anders Permin ${ }^{3}$, 6 Torben W. Schou ${ }^{4}$, Dorte F. Vadekær ${ }^{2}$, Gregers Jungersen ${ }^{2}$ and Helle R. Juul-Madsen ${ }^{1}$

$8 \quad{ }^{1}$ Department of Animal Science, Aarhus University, Blichers Alle 20, DK-8830 Tjele

$9{ }^{2}$ National Veterinary Institute, Division of Veterinary Diagnostics and Research, Technical 10 University of Denmark, Bülowsvej 27, DK-1870 Frederiksberg C

$11{ }^{3}$ National Food Institute, Technical University of Denmark, Mørkhøj Bygade 19, DK-2860 Søborg

$12 \quad{ }^{4}$ Department of Environment and Toxicology, DHI, Agern Allé 5, DK-2970 Hørsholm

$13 \quad$ *Corresponding author: Tina.Dalgaard@agrsci.dk

14 
Ascaridia galli is a gastrointestinal nematode infecting chickens (Permin et al., 1999; Permin et al., 1997). Substitution of traditional cages with alternative rearing systems in modern poultry production has led to an increase in the prevalence of $A$. galli and recent reports from Denmark and neighbouring countries show that the majority of chickens kept in free-range systems are indeed infected with A. galli (Jansson et al., 2010; Kaufmann et al., 2011; Permin et al., 1999). Infection with A. galli may directly contribute to economic losses due to higher feed conversion rates/reduced weight gain and decreased egg production (Permin and Ranvig, 2001; Skallerup et al., 2005). In severe cases, $A$. galli infections are furthermore associated with increased mortality (Das et al., 2010; Gauly et al., 2005; Kilpinen et al., 2005; Permin et al., 2006), increased susceptibility to secondary infections (Dahl et al., 2002; Eigaard et al., 2006; Permin etal., 2006; Saif et al., 2003), impaired vaccine responses (Pleidrup et al., 2014) and even migration of worms into eggs of laying hens (Fioretti et al., 2005; Reid et al., 1973). Previously, A. galli control has been based on synthetic anthelmintics, but concerns about parasite drug resistance and left-over residues in food products call for alternative disease control strategies (Sangster, 1999). An attractive alternative is vaccination, but no successful $A$. galli vaccines have yet been developed.

Natural acquired immunity is described for avian coccidiosis, another important parasitic disease. Thus, trickle immunization may induce immunity against homologous Eimeria challenge (Brake et al., 1997; Joyner and Norton, 1973). Extensive Eimeria studies have been performed in order to understand host protective immune responses and aid vaccine development (Lillehoj et al., 2007). Natural acquired immunity against $A$. galli is less well described, but reports exist on variability in disease susceptibility. The outcome of infection may e.g. be influenced by age (Idi et al., 2004; 
Tongson and McCraw, 1967) and host genetics (Herd and McNaught, 1975; Kaufmann et al., 2011; Permin and Ranvig, 2001). Estimated heritabilities for resistance/susceptibility to A. galli infections suggest that selective breeding for disease resistance may be possible (Gauly et al., 2002; Kaufmann et al., 2011; Schou et al., 2003). In addition, several reports describe the presence of very small larvae (with so called arrested development) in the late stages of an $A$. galli infection and acquired immunity was suggested to be related to this phenomenon (Chamanza et al., 1999a; Ferdushy et al., 2014; Herd and McNaught, 1975). Interestingly, Herd et al. (1975) reported that the proportion of larvae with arrested development was very low in chickens treated with an immunosuppressive agent. In general, it appears that development of anti-helminthic vaccines is far more challenging than the development of vaccines directed against viral and bacterial pathogens. This is in part due to their complex life cycles and the changing host-pathogen interactions occurring during different stages of helminth infections. Thus, a detailed understanding of anti-helminth immunity is essential for future disease control.

The life cycle of $A$.galli is direct, starting with embryonation of shedded eggs in litter or soil. After 10-20 days infective L3 stage larvae are found within the parasite eggs (Permin et al., 1997). When ingested by chickens, the $A$. galli eggs hatch within the first 24 hours either in the proventiculus or the duodenum of the host (Idi et al., 2004; Saif et al., 2003). After three to nine days the larvae enter their histotrophic phase where they move deeper into the mucosal layers of the intestine (Luna-Olivares et al., 2012; Saif et al., 2003; Tugwell and Ackert, 1952). Larvae recovery from the intestinal wall during the first week of infection was highest in the anterior part of the jejunum, but after day 7 post infection (p.i.) larvae was also found in the posterior part of the jejunum (Ferdushy et al., 2013). A high infection dose of parasite eggs may lead to a prolonged histotrophic phase, but usually young adult worms return to the intestinal lumen by day 17-30 of age during 
61 which period co-existence of larvae in the intestinal wall and young worms in the intestinal

62

63

64

65

66

67

79 content is seen (Ferdushy et al., 2013; Herd and McNaught, 1975; Katakam et al., 2010). Recently, Luna-Olivares et al. (2012) suggested that "mucosal phase" may be a more appropriate term than "histotrophic phase" (lamina propria invasive) as the larvae may not penetrate as deep into the intestinal tissue as originally thought. They reported that most larvae were observed in the lumen (but in close contact with the epithelium) (63\%) followed by "within epithelium" (32\%) and only few in the lamina propria (5\%). However, only the very early time-point 3 days p.i. was investigated and it is uncertain what happened later in the histotrophic/mucosal phase. However, Katakam et al. (2010) was able to recover all larvae by an EDTA method, i.e. no additional larvae were recovered when applying additional pepsin digestion after EDTA incubation of intestinal samples taken 2 weeks p.i. indicating that lamina propria associated larvae are few also at this time point.

The chicken spleen works as a secondary lymphoid organ where innate and adaptive immune responses are efficiently mounted. It is hypothesized that the avian spleen plays an even more important immunological role than in mammals as avian lymphatic vessels and lymph nodes are poorly developed. The aim of this study was to investigate systemic immunological responses at different stages of an $A$. galli infection by comparing gene expression profiles in spleen tissue between infected and control chickens at week 2, 6 and 9 post infection (p.i.).

\section{Materials and Methods}

\subsection{Animals}


In the experiment, chickens of mixed gender from the Aarhus University L133 were used. Line 133 is of White Leghorn origin and contains only birds with the major histocompatibility complex (MHC) haplotype B13. Water and commercial chicken feed were supplied ad libitum. The lighting period was $12 \mathrm{~h}$ daily, and the chickens were kept at a temperature of $21^{\circ} \mathrm{C}$. All experimental chickens were produced from MHC-characterized parents, and the MHC haplotypes of the offspring were confirmed by genotyping the LEI0258 microsatellite locus (McConnell et al., 1999) by PCR-based fragment analysis as earlier described (Dalgaard et al., 2005). Some birds in the current experiment were shared with an already published experiment (Pleidrup et al., 2014).

\subsection{Experimental outline}

Experimental chickens were divided into two treatment groups; 1) negative control chickens and 2) chickens subjected to $A$. galli infection that were kept in separate rooms of the chicken facility. At 4 weeks of age, chickens in group 2 were orally infected with 1750 embryonated $A$. galli eggs recovered from female worm uteri obtained from naturally infected commercial hens and embryonated in $\mathrm{H} 2 \mathrm{SO} 4$ as described in Permin et al. (1997). Sixteen animals from each group were used for weekly blood sampling and seven other animals from each group were sacrificed at week 2, 6 and 9 p.i. for spleen collection. At week 6 and 9 p.i. faecal samples were collected before sacrificing the chickens. Licence to conduct the animal experiment was obtained from the Danish Ministry of Justice, Animal Experimentation Inspectorate by Helle R. Juul-Madsen. The experiment was conducted according to the ethical guidelines

\subsection{A. galli-specific IgG ELISA}


Blood samples from infected animals were taken at weeks $0,6,7,8,9$ p.i. and from negative controls at week 0, 6, 9 p.i. and serum was used for detection of $A$. galli-specific IgG antibodies as earlier described (Norup et al., 2013).

\subsection{Faecal A. galli egg excretion}

Faecal samples were obtained from A. galli-infected chickens before sacrificing them for spleen sampling at weeks 6 and 9 p.i. Faeces was not sampled from chickens sacrificed 2 weeks p.i. as adult egg secreting worms are not developed until week 5-8 p.i. (Permin and Hansen, 1998). The faecal samples were examined for the presence of $A$. galli eggs using a modified McMaster counting technique (Henriksen and Aagaard, 1976; Permin et al., 1997) with a detection limit of 20 eggs per gram faeces (EPG).

\subsection{RNA extraction}

After collection, spleens were sectioned (triangular cross-sectional slice from upper part) and identical samples from each chicken were immediately placed in RNAlater (Ambion/Life Technologies), kept overnight at $4^{\circ} \mathrm{C}$ and then at $-20^{\circ} \mathrm{C}$ until further processing. Amounts of 7 to 15 mg tissue were homogenised on a Tissuelyzer LT (Qiagen), and RNA isolation and DNA digestion was done using the NucleoSpin 96 RNA kit (Macherey-Nagel) according to the manufacturer's instructions. RNA quality was controlled on a $1 \%$ agarose gel and the RNA concentration and purity were determined using a NanoDrop spectrophotometer (Saveen and Werner AB).

\section{6. cDNA synthesis and pre amplification of $m R N A$}


cDNA synthesis and preamplification was performed as described previously (Skovgaard et al., 2013). Extracted total RNA was converted into cDNA by reverse transcription of 480 ng RNA using the QuantiTECT Reverse Transcription kit (Qiagen), cDNA was diluted 1:5 in low EDTA TE-buffer (VWR - Bie \& Berntsen) prior to preamplification. Preamplification was performed using TaqMan PreAmp Master Mix (Applied Biosystems) and a 200 nM pooled primer mix was prepared combining each primer used in the present study. TaqMan PreAmp Master Mix (5 $\mu$ l) was mixed with $2.5 \mu \mathrm{l} 200 \mathrm{nM}$ pooled primer mix and $2.5 \mu \mathrm{l}$ diluted CDNA, and incubated at $95^{\circ} \mathrm{C}$ for $10 \mathrm{~min}$ and 16 cycles of $95^{\circ} \mathrm{C}$ for $15 \mathrm{sec}$ and $60^{\circ} \mathrm{C}$ for $4 \mathrm{~min} .16 \mathrm{U}$ of Exonuclease I (New England BioLabs) was added to the preamplified cDNA, thermal cycling conditions were set to $37^{\circ} \mathrm{C}$ for $30 \mathrm{~min}$ followed by $80^{\circ} \mathrm{C}$ for 15 min. Preamplified cDNA was diluted 1:10 in low EDTA TE-buffer (VWR Bie \& Berntsen) before qPCR. Primers were designed using Primer3 (http://bioinfo.ut.ee/primer3$\underline{0.4 .0 /)}$ as described in (Skovgaard et al., 2010), and purchased from Sigma-Aldrich. Primer sequences, efficiencies and amplicon length are shown in Table 1.

\section{7. $q P C R$}

Gene expression mRNA was analysed by quantitative real-time PCR (qPCR) performed in Dynamic Array Integrated Fluidic Circuits (Fluidigm) following the protocol described previously (Skovgaard et al., 2013). The following cycle parameter was used: $2 \mathrm{~min}$ at $50^{\circ} \mathrm{C}, 10 \mathrm{~min}$ at $95^{\circ} \mathrm{C}$, followed by 35 cycles with denaturing for $15 \mathrm{sec}$ at $95^{\circ} \mathrm{C}$ and annealing/ elongation for $1 \mathrm{~min}$ at $60^{\circ} \mathrm{C}$. Melting curves were generated after each run to confirm a single PCR product (from $60^{\circ} \mathrm{C}$ to $95^{\circ} \mathrm{C}$, increasing $1^{\circ} \mathrm{C} / 3 \mathrm{sec}$ ). Reactions were performed in duplicates (cDNA replicates). Non template controls (NTC) were included to indicate potential problems with non-specific amplification or 
sample contaminations. Non-reverse transcriptase controls were included to assess potential DNA contamination.

Expression data (Cq values) were acquired using the Fluidigm Real-Time PCR Analysis software 3.0.2 (Fluidigm) and exported to GenEx (MultiD) for data pre-processing including interplate correction, correction for PCR efficiency for each primer assay individually, normalising to six highly stable reference genes, and averaging of cDNA technical repeats. Using GeNorm (17) and NormFinder (18), glyceraldehyde-3-phosphate dehydrogenase (GAPDH), $\beta 2$ microglobulin (B2M), peptidylprolyl isomerase A (PPIA), hypoxanthine phosphoribisyl transferase I (HRPT1), TATA-box binding protein (TBP), and tyrosine 3-monooxygenase/tryptophan 5-monooxygenase activation protein, zeta polypeptide (YWHAE) were identified as the most stably expressed reference genes out of eight candidates. For each primer assay, the mean relative expression level of the control group was scaled to one during data transformation log2 (Cq) to linear scale. Gene expression data were $\log _{2}$-transformed before testing for normal distribution, Student $t$ test was used to analyse normally distributed data, while the non-parametric test (Wilcoxon-Mann-Whitney test) was used when data was non-normal distributed. Gene expression was considered significantly different if the $P$ value was less than 0.05 and the relative expression was greater than 2.0. Experimental practice and reporting have been performed according to the Minimum Information for Publication of Quantitative Real-Time PCR Experiments (MIQE) guidelines (Bustin et al., 2009).

\section{Results and Discussion}

According to earlier studies, week 2 p.i. represents the mucosal phase of the $A$. galli larvae whereas at weeks 6 and 9 adult worms are present in the intestinal lumen. In the present 
experiment only $43 \%$ of the animals (data not shown) shedded A. galli eggs in faeces at week 6 p.i., and we hypothesise that the $A$. galli worms are young and have just recently started producing eggs. Presumably some larvae are also still present in the mucosa at this time point as earlier reported by Ferdushi et al. (2013). In contrast, $73 \%$ of the chickens (data not shown) shedded $A$. galli eggs in faeces at week 9 p.i. and with a higher mean EPG per animal than at week 6 (Figure 1a). Thus, this time point may represent more mature adult worms. None of the chickens in the A. galli-free group tested EPG positive at any time-point during the experiment (data not shown). Additional chickens allocated to blood sampling were sero-negative at the day of infection (data not shown). Chickens in the blood sampled A. galli-inoculated group had seroconverted by week 6 p.i. and showed positive titres of $A$. galli-specific serum IgG throughout the rest of the experiment. Chickens from the blood sampled negative control group were tested at weeks 6 and 9 p.i. and were found to be sero-negative at both time-points (Fig. 1.b). A systemic humoral immune response is reported by others as early as 2 weeks p.i., but serum titres do not appear to correlate with egg excretion or worm burden (Marcos-Atxutegi et al., 2009; Norup et al., 2013; Schwarz et al., 2011).

In order to understand systemic molecular response mechanisms in different stages of an $A$. galli infection we studied gene expression profiles in spleen sampled 2, 6 and 9 weeks after the experimental infection. Twelve genes (representing inflammatory cytokines, antimicrobial peptides, acute phase proteins, soluble pattern recognition receptors and $\mathrm{T}$ cell signature cytokines) were differentially expressed $(P<0.05)$ at at least one of the three analysed time points after the $A$. galli infection compared to the control group. 
191

192

193

194

195

196

197

198

199

200

201

202

203

204

205

206

207

208

209

210

211

\section{1. (Pro-)Inflammatory cytokines}

Only few studies have been published concerning innate immune responses towards $A$. galli in chickens and focus has been on local responses in the small intestine. Thus, a single study reports increased numbers of mast cells in the chicken jejunum 2 weeks post $A$. galli infection (Darmawi et al., 2013). Another study reports increased numbers of presumably heterophils in the jejunum 3 days after an A. galli infection (Luna-Olivares et al., 2012). Interestingly, a genetic association study indicated that chicken IFN- $\gamma$ gene variants may influence $A$. galli susceptibility (Luhken et al., 2011). In the present study, we analysed the expression of inflammatory cytokines in the spleen (Table 2). Surprisingly, the expression of IFN- $\alpha, \mathrm{IL}-1 \beta, \mathrm{IL}-12 \beta$ and II-18 was up regulated at week 6 p.i., but not at week 2 p.i. or week 9 p.i. The IL-8 expression was up regulated at week 2 as well as week 6 p.i. in A. galli-infected chickens. Despite structural differences most avian cytokines display conserved functions compared to their mammalian counterparts (Staeheli et al., 2001), and roles in the chicken inflammatory response have been described for IL-8, IL-1 $\beta, I L-18, I L-12 \beta$ (Balu and Kaiser, 2003; Barker et al., 1993; Laurent et al., 2001; Schneider et al., 2000; Weining et al., 1998; Withanage et al., 2004). Also chicken IFN- $\alpha$ (ChIFN-I) was identified to have a similar function to the mammalian counterpart as a potent antiviral agent (Schultz et al., 1995; Sick et al., 1996). It is now accepted that IFN- $\alpha$ in mammals beside its antiviral properties shows additional immunomodulating effects. Although little is known of IFN- $\alpha$ 's role in parasite infections, treatment of helminth disease in mice has been attempted with recombinant IFN- $\alpha$ (Godot et al., 2003).

\subsection{Antimicrobial peptides}


The expression of DEF $\beta 1$ was significantly reduced at week 2 p.i. and significantly increased at weeks 6 and 8 p.i. in spleen tissue of $A$. galli-infected chickens (Table 2). Antimicrobial peptides like defensins play an important role in innate immunity, and activity directed against bacteria, fungi and viruses has been reported (Ganz, 2003). Interestingly, defensins may influence adaptive immune responses as they can affect the maturation of dendritic cells as well as effector T cell recruitment (Yang et al., 2002). In the chicken genome, 14 beta-defensin/gallinacin genes exist and the nomenclature AvBD1-14 was suggested (Lynn et al., 2007). Local expression of several of the AvBD genes and their antimicrobial activity against avian enteric pathogens have been described (Evans and Harmon, 1995; Harmon, 1998; Hong et al., 2012; Sugiarto and Yu, 2004). However, the role of AvBD in innate immunity towards helminth infections is not clear. In humans, some betadefensins are up regulated by pro inflammatory cytokines (McDermott et al., 2006; Scott and Hancock, 2000). In the present study an increased expression of DEF $\beta 1 / A v B D 1$ coincided with an increase in the expression of pro-inflammatory cytokine genes at week 6 p.i., but not at week 9 p.i.

\subsection{Acute phase proteins}

Mannose binding protein $(\mathrm{MBL})$ and C-reactive protein (CRP) are soluble pattern recognition receptors. Few reports exist on chicken CRP, but it appears that infections with Eimeria spp. and Histomonas meleagridis induce high levels of CRP (Chamanza et al., 1999). In mammals, MBL binds to microbial surface carbohydrates and mediates opsonophagocytosis directly or through activation of the lectin complement pathway. A conserved function of $M B L$ in the chicken was suggested as $\mathrm{CMBL}$ in a heterologous in vitro assay was shown to enhance human complement factor 4 (C4) deposition in a calcium dependent way (Norup and Juul-Madsen, 2007). As in mammals, reduced levels of serum MBL in chickens may lead to increased disease susceptibility to 
viral and bacterial infections (Juul-Madsen et al., 2007; Schou et al., 2010). Chicken MBL is mainly produced in the liver, but constitutive and inducible local expression of the gene has also been reported (Hogenkamp et al., 2006; Laursen et al., 1998; Nielsen et al., 1998). In this study, MBL expression was significantly increased in spleen tissue of $A$. galli-infected chickens 6 weeks p.i. (Table 2). An in vivo function of MBL in intestinal helminth infections has not yet been determined, but preliminary results suggest that faecal shedding of $A$. galli eggs is reduced in infected inbred chickens with high MBL serum levels (unpublished, Norup).

\subsection{Th signature cytokines}

In mammals, Th2 polarised cells drive responses to helminth infections. Also in the chicken a Th2 polarised cytokine response was reported in the jejunum and spleen of $A$. galli-infected chickens 2 weeks p.i. (Degen et al., 2005; Kaiser, 2007; Pleidrup et al., 2014; Schwarz et al., 2011). In agreement with former studies, we observed an increased expression of the Th2 signature cytokine IL-13 at 2 weeks p.i. in the spleen of $A$. galli-infected chickens, but not at later stages of the infection (Table 2). This time-point corresponds to the mucosal phase of the infection which co-incides with influx of both $\alpha \beta$ (including CD4+ve cells) and $\gamma \delta$ T cells in the jejunal mucosa as reported by others (Schwarz et al., 2011). In the present study we observed a slightly decreased expression of the Th1 signature cytokine IFN- $\gamma$ at week 9 p.i. in spleen tissue of $A$. galli-infected chickens. This observation is in contrast to earlier findings by Degen et al. (2005) who reported decreased relative cytokine mRNA ratios (infected/non-infected) for IFN- $\gamma$ as early as 2 weeks p.i.

Earlier reports do suggest that onset and length of the larvae mucosal phase depend on infection dose which differed between the two experiments.

\subsection{Anti-inflammatory cytokines}


In human and murine infections the survival strategy of helminth parasites is largely based on immunoregulation by excretory-secretory (ES) products through mechanisms involving regulatory T cells (Taylor et al., 2012). No Foxp3 orthologue has been identified in the chicken, but thymic CD4+CD25+ T cells were characterised as counterparts of mammalian natural Tregs by production of IL-10 and TGF- $\beta$ (Shanmugasundaram and Selvaraj, 2011). In the present study, an increased expression of TGF- $\beta 4$ was observed 6 weeks p.i. in spleen tissue of $A$. galli- infected chickens (Table 2). The chicken TGF- $\beta$ gene-family includes: TGF- $\beta 2$, TGF- $\beta 3$ and TGF- $\beta 4$, of which the latter is the chicken orthologue of mammalian TGF- $\beta 1$ acting as an anti-inflammatory cytokine (Jakowlew et al., 1997; Pan and Halper, 2003). IL-10 has a conserved function in the chicken acting as an anti-inflammatory cytokine (Rothwell et al., 2004). No increased expression of IL-10 was observed in the present study; instead the expression was lower in the spleen tissue of $A$. galliinfected chickens 6 and 9 weeks p.i. than in controls where expression increased by age (data not shown). We have no explanation for this and further studies in other inbred chicken lines as well as outbred lines need to be conducted in order to elucidate if this is a general response in A. galli infections. Further studies of the expression of anti-inflammatory cytokines may also help us to understand why $A$. galli infected chickens appear to have impaired vaccine responses towards third party antigens (Pleidrup et al., 2014).

\subsection{Conclusion}

In summary, we have investigated the avian systemic immune response to $A$. galli infection by expression analyses of immune genes in spleen. Interestingly, we observed only few differentially expressed genes at week 2 p.i. which corresponds to the larvae mucosal phase. In contrast, by 
278 lumen, we observed increased expression of pro-inflammatory cytokines and acute phase 279 proteins. It is yet to be determined if the observed pro-inflammatory response is caused by $A$. galli 280 specific pathogen-associated molecular pattern molecules (PAMPs), host specific damage281 associated molecular pattern molecules (DAMPs) released by tissue damage, DAMP homologues 282 in parasite secretions of even by opportunistic secondary infections.

285 The authors declare to have no conflicts of interest.

\section{Acknowledgements}

287 The authors wish to acknowledge financial support from The Danish Council for Strategic 288 Research, Aarhus University and the European Union Seventh Framework Network of Animal 289 Disease Infectiology Research Facilities (NADIR; reference number FP7-228394). Pete Kaiser and 290 Lisa Rothwell are thanked for fruitful comments and support, Karin Tarp, Lene Rosborg Dal and 291 Helle Handll for excellent technical assistance, and Karin V. Østergaard for proof reading of the 292 manuscript. 
Balu, S., Kaiser, P., 2003. Avian interleukin-12beta (p40): cloning and characterization of the cDNA and gene. Journal of interferon \& cytokine research : the official journal of the International Society for Interferon and Cytokine Research 23, 699-707.

Barker, K.A., Hampe, A., Stoeckle, M.Y., Hanafusa, H., 1993. Transformation-associated cytokine 9E3/CEF4 is chemotactic for chicken peripheral blood mononuclear cells. Journal of virology 67, 3528-3533.

Brake, D.A., Fedor, C.H., Werner, B.W., Miller, T.J., Taylor, R.L., Jr., Clare, R.A., 1997. Characterization of 301 immune response to Eimeria tenella antigens in a natural immunity model with hosts which differ serologically at the B locus of the major histocompatibility complex. Infection and immunity 65, 1204-1210.

Bustin, S.A., Benes, V., Garson, J.A., Hellemans, J., Huggett, J., Kubista, M., Mueller, R., Nolan, T., Pfaffl, M.W., Shipley, G.L., Vandesompele, J., Wittwer, C.T., 2009. The MIQE guidelines: minimum information for publication of quantitative real-time PCR experiments. Clinical chemistry 55, 611-622.

Chamanza, R., van Veenm, L., Tivapasi, M.T., Toussaint, M.J.M., 1999. Acute phase proteins in the domestic 307 fowl. World's Poultry Science Journal 55, 61-71. chickens. Veterinary microbiology 86, 313-324.

Dalgaard, T.S., Vitved, L., Skjodt, K., Thomsen, B., Labouriau, R., Jensen, K.H., Juul-Madsen, H.R., 2005. Molecular characterization of major histocompatibility complex class I (B-F) mRNA variants from chickens differing in resistance to Marek's disease. Scandinavian journal of immunology 62, 259-270. 
Das, G., Kaufmann, F., Abel, H., Gauly, M., 2010. Effect of extra dietary lysine in Ascaridia galli-infected grower layers. Veterinary parasitology 170, 238-243.

Degen, W.G., Daal, N., Rothwell, L., Kaiser, P., Schijns, V.E., 2005. Th1/Th2 polarization by viral and helminth infection in birds. Veterinary microbiology 105, 163-167.

Eigaard, N.M., Schou, T.W., Permin, A., Christensen, J.P., Ekstrom, C.T., Ambrosini, F., Cianci, D., Bisgaard, M., 2006. Infection and excretion of Salmonella Enteritidis in two different chicken lines with concurrent Ascaridia galli infection. Avian pathology : journal of the W.V.P.A 35, 487-493.

Evans, E.W., Harmon, B.G., 1995. A review of antimicrobial peptides: defensins and related cationic peptides. Veterinary clinical pathology / American Society for Veterinary Clinical Pathology 24, 109-116.

Ferdushy, T., Luna-Olivares, L.A., Nejsum, P., Roepstorff, A.K., Thamsborg, S.M., Kyvsgaard, N.C., 2013. Population dynamics of Ascaridia galli following single infection in young chickens. Parasitology 140, 10781084.

Ferdushy, T., Schou, T.W., Norup, L.R., Dalgaard, T.S., Thamsborg, S.M., Nejsum, P., Permin, A., JuulMadsen, H.R., Kyvsgaard, N.C., 2014. Acquisition of resistance after continuous infection with Ascaridia galli in chickens. Parasitology, 1-8.

Fioretti, D.P., Veronesi, F., Diaferia, M., Franciosini, M.P., Proietti, P.C., 2005. Ascaridia galli: a report of erratic migration. Ital J Anim Sci 4, 310-312.

Ganz, T., 2003. Defensins: antimicrobial peptides of innate immunity. Nature reviews. Immunology 3, 710720.

Gauly, M., Bauer, C., Preisinger, R., Erhardt, G., 2002. Genetic differences of Ascaridia galli egg output in laying hens following a single dose infection. Veterinary parasitology 103, 99-107. 
Gauly, M., Homann, T., Erhardt, G., 2005. Age-related differences of Ascaridia galli egg output and worm burden in chickens following a single dose infection. Veterinary parasitology 128, 141-148. mice against a helminth infection of the liver and modulates immune responses. Gastroenterology 124, 1441-1450.

Harmon, B.G., 1998. Avian heterophils in inflammation and disease resistance. Poultry science 77, 972-977.

Henriksen, S.A., Aagaard, K., 1976. [A simple flotation and McMaster method (author's transI)]. Nordisk veterinaermedicin 28, 392-397.

Herd, R.P., McNaught, D.J., 1975. Arrested development and the histotropic phase of Ascaridia galli in the chicken. International journal for parasitology 5, 401-406.

Hogenkamp, A., van Eijk, M., van Dijk, A., van Asten, A.J., Veldhuizen, E.J., Haagsman, H.P., 2006. Characterization and expression sites of newly identified chicken collectins. Molecular immunology 43, $1604-1616$.

Hong, Y.H., Song, W., Lee, S.H., Lillehoj, H.S., 2012. Differential gene expression profiles of beta-defensins in 351 the crop, intestine, and spleen using a necrotic enteritis model in 2 commercial broiler chicken lines. 352 Poultry science 91, 1081-1088. Idi, A., Permin, A., Murrell, K.D., 2004. Host age only partially affects resistance to primary and secondary 354 infections with Ascaridia galli (Schrank, 1788) in chickens. Veterinary parasitology 122, 221-231. 
Jansson, D.S., Nyman, A., Vagsholm, I., Christensson, D., Goransson, M., Fossum, O., Hoglund, J., 2010. Ascarid infections in laying hens kept in different housing systems. Avian pathology : journal of the W.V.P.A $39,525-532$.

Joyner, L.P., Norton, C.C., 1973. The immunity arising from continuous low-level infection with Eimeria tenella. Parasitology 67, 333-340.

Juul-Madsen, H.R., Norup, L.R., Handberg, K.J., Jorgensen, P.H., 2007. Mannan-binding lectin (MBL) serum concentration in relation to propagation of infectious bronchitis virus (IBV) in chickens. Viral immunology $20,562-570$.

Kaiser, P., 2007. The avian immune genome--a glass half-full or half-empty? Cytogenetic and genome research $117,221-230$.

Katakam, K.K., Nejsum, P., Kyvsgaard, N.C., Jorgensen, C.B., Thamsborg, S.M., 2010. Molecular and parasitological tools for the study of Ascaridia galli population dynamics in chickens. Avian pathology : journal of the W.V.P.A 39, 81-85.

Kaufmann, F., Das, G., Preisinger, R., Schmutz, M., Konig, S., Gauly, M., 2011. Genetic resistance to natural helminth infections in two chicken layer lines. Veterinary parasitology 176, 250-257.

Kilpinen, O., Roepstorff, A., Permin, A., Norgaard-Nielsen, G., Lawson, L.G., Simonsen, H.B., 2005. Influence of Dermanyssus gallinae and Ascaridia galli infections on behaviour and health of laying hens (Gallus gallus domesticus). British poultry science $46,26-34$.

Laurent, F., Mancassola, R., Lacroix, S., Menezes, R., Naciri, M., 2001. Analysis of chicken mucosal immune response to Eimeria tenella and Eimeria maxima infection by quantitative reverse transcription-PCR. Infection and immunity 69, 2527-2534. 
Laursen, S.B., Hedemand, J.E., Nielsen, O.L., Thiel, S., Koch, C., Jensenius, J.C., 1998. Serum levels, ontogeny and heritability of chicken mannan-binding lectin (MBL). Immunology 94, 587-593.

Lillehoj, H.S., Kim, C.H., Keeler, C.L., Jr., Zhang, S., 2007. Immunogenomic approaches to study host immunity to enteric pathogens. Poultry science $86,1491-1500$.

Luhken, G., Gauly, M., Kaufmann, F., Erhardt, G., 2011. Association study in naturally infected helminth 384 layers shows evidence for influence of interferon-gamma gene variants on Ascaridia galli worm burden. Veterinary research $42,84$.

Luna-Olivares, L.A., Ferdushy, T., Kyvsgaard, N.C., Nejsum, P., Thamsborg, S.M., Roepstorff, A., Iburg, T.M., 387 2012. Localization of Ascaridia galli larvae in the jejunum of chickens 3 days post infection. Veterinary parasitology 185, 186-193.

Lynn, D.J., Higgs, R., Lloyd, A.T., O'Farrelly, C., Herve-Grepinet, V., Nys, Y., Brinkman, F.S., Yu, P.L., Soulier, 390

Marcos-Atxutegi, C., Gandolfi, B., Aranguena, T., Sepulveda, R., Arevalo, M., Simon, F., 2009. Antibody and inflammatory responses in laying hens with experimental primary infections of Ascaridia galli. Veterinary parasitology 161, 69-75.

McConnell, S.K., Dawson, D.A., Wardle, A., Burke, T., 1999. The isolation and mapping of 19 tetranucleotide microsatellite markers in the chicken. Animal genetics 30, 183-189.

McDermott, A.M., Rich, D., Cullor, J., Mannis, M.J., Smith, W., Reid, T., Murphy, C.J., 2006. The in vitro activity of selected defensins against an isolate of Pseudomonas in the presence of human tears. The British journal of ophthalmology 90, 609-611. 
Nielsen, O.L., Jorgensen, P.H., Hedemand, J., Jensenius, J.C., Koch, C., Laursen, S.B., 1998. Immunohistochemical investigation of the tissue distribution of mannan-binding lectin in non-infected and virus-infected chickens. Immunology 94, 122-128.

Norup, L.R., Dalgaard, T.S., Pleidrup, J., Permin, A., Schou, T.W., Jungersen, G., Fink, D.R., Juul-Madsen, H.R., 2013. Comparison of parasite-specific immunoglobulin levels in two chicken lines during sustained infection with Ascaridia galli. Veterinary parasitology 191, 187-190.

Norup, L.R., Juul-Madsen, H.R., 2007. An assay for measuring the mannan-binding lectin pathway of complement activation in chickens. Poultry science 86, 2322-2326.

Pan, H., Halper, J., 2003. Cloning, expression, and characterization of chicken transforming growth factor beta 4. Biochemical and biophysical research communications 303, 24-30.

Permin, A., Bisgaard, M., Frandsen, F., Pearman, M., Kold, J., Nansen, P., 1999. Prevalence of gastrointestinal helminths in different poultry production systems. British poultry science 40, 439-443.

Permin, A., Bojesen, M., Nansen, P., Bisgaard, M., Frandsen, F., Pearman, M., 1997. Ascaridia galli populations in chickens following single infections with different dose levels. Parasitology research 83, 614617.

Permin, A., Christensen, J.P., Bisgaard, M., 2006. Consequences of concurrent Ascaridia galli and Escherichia coli infections in chickens. Acta veterinaria Scandinavica 47, 43-54.

Permin, A., Ranvig, H., 2001. Genetic resistance to Ascaridia galli infections in chickens. Veterinary parasitology 102, 101-111.

Pleidrup, J., Dalgaard, T.S., Norup, L.R., Permin, A., Schou, T.W., Skovgaard, K., Vadekaer, D.F., Jungersen, G., Sorensen, P., Juul-Madsen, H.R., 2014. Ascaridia galli infection influences the development of both humoral and cell-mediated immunity after Newcastle Disease vaccination in chickens. Vaccine 32, 383-392. 
Reid, W.M., Mabon, J.L., Harshbarger, W.C., 1973. Detection of worm parasites in chicken eggs by candling.

Rothwell, L., Young, J.R., Zoorob, R., Whittaker, C.A., Hesketh, P., Archer, A., Smith, A.L., Kaiser, P., 2004.

425 Cloning and characterization of chicken IL-10 and its role in the immune response to Eimeria maxima. 426 Journal of immunology 173, 2675-2682. Wiley.

Sangster, N.C., 1999. Anthelmintic resistance: past, present and future. International journal for parasitology 29, 115-124; discussion 137-118.

Schneider, K., Puehler, F., Baeuerle, D., Elvers, S., Staeheli, P., Kaspers, B., Weining, K.C., 2000. cDNA cloning of biologically active chicken interleukin-18. Journal of interferon \& cytokine research : the official journal of the International Society for Interferon and Cytokine Research 20, 879-883. Ascaridia galli infections of 4 different commercial layer-lines. British poultry science 44, 182-185. journal of immunology $25,847-851$. 

Immunopathogenesis of Ascaridia galli infection in layer chicken. Developmental and comparative immunology 35, 774-784.

Scott, M.G., Hancock, R.E.W., 2000. Cationic Antimicrobial Peptides and Their Multifunctional Role in the 446 Immune System. 20, 24. Journal of immunology 186, 1997-2002.

Sick, C., Schultz, U., Staeheli, P., 1996. A family of genes coding for two serologically distinct chicken interferons. The Journal of biological chemistry 271, 7635-7639.

Skallerup, P., Luna, L.A., Johansen, M.V., Kyvsgaard, N.C., 2005. The impact of natural helminth infections and supplementary protein on growth performance of free-range chickens on smallholder farms in El Sauce, Nicaragua. Preventive veterinary medicine 69, 229-244.

Skovgaard, K., Cirera, S., Vasby, D., Podolska, A., Breum, S.O., Durrwald, R., Schlegel, M., Heegaard, P.M., 2013. Expression of innate immune genes, proteins and microRNAs in lung tissue of pigs infected experimentally with influenza virus (H1N2). Innate immunity 19, 531-544.

457 Skovgaard, K., Mortensen, S., Boye, M., Hedegaard, J., Heegaard, P.M., 2010. Hepatic gene expression 458 changes in pigs experimentally infected with the lung pathogen Actinobacillus pleuropneumoniae as 459 analysed with an innate immunity focused microarray. Innate immunity 16, 343-353.

460 Staeheli, P., Puehler, F., Schneider, K., Gobel, T.W., Kaspers, B., 2001. Cytokines of birds: conserved 461 functions--a largely different look. Journal of interferon \& cytokine research : the official journal of the 462 International Society for Interferon and Cytokine Research 21, 993-1010. 
Sugiarto, H., Yu, P.L., 2004. Avian antimicrobial peptides: the defense role of beta-defensins. Biochemical and biophysical research communications 323, 721-727.

Taylor, M.D., van der Werf, N., Maizels, R.M., 2012. T cells in helminth infection: the regulators and the regulated. Trends in immunology 33, 181-189.

Tongson, M.S., McCraw, B.M., 1967. Experimental ascaridiasis: influence of chicken age and infective egg dose on structure of Ascaridia galli populations. Experimental parasitology 21, 160-172.

Tugwell, R.L., Ackert, J.E., 1952. On the tissue phase of the life cycle of the fowl nematode Ascaridia galli (Schrank). The Journal of parasitology 38, 277-288.

Weining, K.C., Sick, C., Kaspers, B., Staeheli, P., 1998. A chicken homolog of mammalian interleukin-1 beta: CDNA cloning and purification of active recombinant protein. European journal of biochemistry / FEBS 258, 994-1000.

Withanage, G.S., Kaiser, P., Wigley, P., Powers, C., Mastroeni, P., Brooks, H., Barrow, P., Smith, A., Maskell, D., McConnell, I., 2004. Rapid expression of chemokines and proinflammatory cytokines in newly hatched chickens infected with Salmonella enterica serovar typhimurium. Infection and immunity 72, 2152-2159.

Yang, D., Biragyn, A., Kwak, L.W., Oppenheim, J.J., 2002. Mammalian defensins in immunity: more than just microbicidal. Trends in immunology 23, 291-296. 